\title{
Recharge Estimation of Hard Rock Aquifers under Sahelian Climate Conditions Using Water Table Fluctuation: Case Study of Tougou Catchment, Burkina Faso
}

\author{
Mahamadou Koïta1*, Wennegouda Jean Pierre Sandwidi' ${ }^{2}$, Amagana Emmanuel Dara1 \\ ${ }^{1}$ Institut International d'Ingénierie de l'Eau et de l’Environnement, Ouagadougou, Burkina Faso \\ ${ }^{2}$ Ecole Nationale Supérieure d'Ingénieurs de Fada/Université Ouaga I Professeur Joseph Ki Zerbo, Ouagadougou, Burkina Faso \\ Email: ^mahamadou.koita@2ie-edu.org, ${ }^{\star}$ kmahamoudk@yahoo.fr
}

How to cite this paper: Koïta, M., Sandwidi, W.J.P. and Dara, A.E. (2017) Recharge Estimation of Hard Rock Aquifers under Sahelian Climate Conditions Using Water Table Fluctuation: Case Study of Tougou Catchment, Burkina Faso. Journal of Water Resource and Protection, 9, 1428-1448.

https://doi.org/10.4236/jwarp.2017.912092

Received: August 14, 2017

Accepted: October 16, 2017

Published: November 29, 2017

Copyright $\odot 2017$ by authors and Scientific Research Publishing Inc. This work is licensed under the Creative Commons Attribution International License (CC BY 4.0).

http://creativecommons.org/licenses/by/4.0/

\begin{abstract}
This study aims to characterize water table fluctuations and estimate groundwater recharge in the Tougou catchment located in the Sahel zone of Burkina Faso. Water table fluctuation and groundwater budget approaches are developed on an experimental site equipped with observation wells. The trends of water fluctuations in the different layers of the weathering profile are similar. There is a time-lag response of groundwater recharge to the daily precipitation occurrences. The interaction between the upper (clayey alteration) and lower (transition zone-fractured schist complex) parts of the weathering profile shows that generally the hydraulic head in the upper part is higher than that of the lower part due to difference in drainage porosity. The latter varies at the catchment scale between 0.006 and 0.009 and is inversely proportional to the saturated thickness of the clayey alteration layer. The groundwater recharge is annually estimated between 36 and $49 \mathrm{~mm}$, which correspond to $6 \%$ and $9 \%$ of mean annual rainfall in the catchment. Annual evapotranspiration was estimated to be about 223 to $443 \mathrm{~mm}$.
\end{abstract}

\section{Keywords}

Recharge, Aquifer, Specific Yield, Water Table Fluctuation WTF, Groundwater Budget, Sahel, Tougou, Burkina Faso

\section{Introduction}

Freshwater accessibility is one of the top challenges in Africa, and particularly in the Sahel region. According to the UNEP [1], about 75\% of Africans currently depend on groundwater resources. Population growth together with the en- 
hancement of anthropic activities has led to an increase in water demands. In addition to this, uncertainties about the beginning and end of the seasons, the increase in the number and duration of dry pockets during the wet season, the scarcity or seasonality of surface waters are factors contributing to the pressure on groundwater resources [2]. Indeed, groundwater has been considered less vulnerable to drought [3]. It seems to be the main solution to the challenge of water supply in arid environments. Unfortunately, a lack of hydrogeological knowledge has resulted in over-extraction in some places [4]. No adequate policy on groundwater resource management can be set down without knowledge on groundwater recharge and an aquifer's renewal rate. In crystalline basement aquifers of Sahelian climate, the quantity of recharge to the aquifer is proportional to the annual quantity, rain frequency, and spatial distribution of rainfall as well as the duration of the wet season [5]. Quantification of recharge rate is essential for efficient and sustainable management of groundwater resources [6]. Groundwater recharge can be estimated using various methods according to aquifer recharge processes. Groundwater recharge estimation is made of complexities due to differences in recharge processes between aquifers [7].

Tougou catchment in the Sahel region of Burkina Faso also supports this crucial reality of groundwater recharge estimation. In this research site, climate variability and a lack of sufficient and permanent surface water supply have forced the local population to use groundwater resources as the main source of freshwater. This situation has 1) induced more pressures on groundwater resources in the area; 2) induced problems in obtaining enough water for local people use; and 3) degraded the soil which has led to a decrease in water infiltration and percolation to aquifers. Rapid population growth and climate and environmental changes call decision makers to improve knowledge on resources for rational and sustainable development and management. Recharge estimation is a key to rational and sustainable exploitation of groundwater resource. In order to assist in the development of policies that favor adequate use of water resources proportionally to their renewal rate, this research was undertaken in the Yatenga province with Tougou experimental site serving as the case study. The research aims at characterizing water table fluctuations of the Tougou catchment aquifer and estimating recharge by using a combination of the water balance equation and the water table fluctuation method. The combination of the two approaches is an innovative way to estimate specific yield and direct recharge [8] [9].

In the following sections, the Tougou experimental site description is presented as well as the methods used to determine the water budget parameters and the specific yield.

\section{Study Site}

Tougou catchment, a river catchment with an area of about $37 \mathrm{~km}^{2}$, is located in the northern part of the Yatenga province in Burkina Faso (Figure 1).

The catchment is part of the Nakambé River catchment which is one of the 
three main river catchments of Burkina Faso. The Tougou River catchment is under Sahelian climate with a mean annual rainfall of $600 \mathrm{~mm}$. Daily temperature varies from $17^{\circ} \mathrm{C}$ to $40^{\circ} \mathrm{C}$. The surface water network consists mainly of streams and gullies. The main feature, Bilampouanga River, is dry most of the time, except for a few days a year after very heavy rainfall. The catchment geomorphology is characterized by a long narrow valley bottom oriented N60. The relief is relatively flat (altitudes varying between $320 \mathrm{~m}$ and $366 \mathrm{~m}$ ). In general, there are two main vegetation types in the Tougou catchment: the steppe and the agroforestry. The steppe, which is a sparse vegetation covering very few soils is the most important in terms of area. It is found on the slopes of hillocks, hills, low glacis and old fallows [10]. On the other hand, the agroforestry area is more or less dense with a fairly high soil cover rates. Located in the valley-bottom and

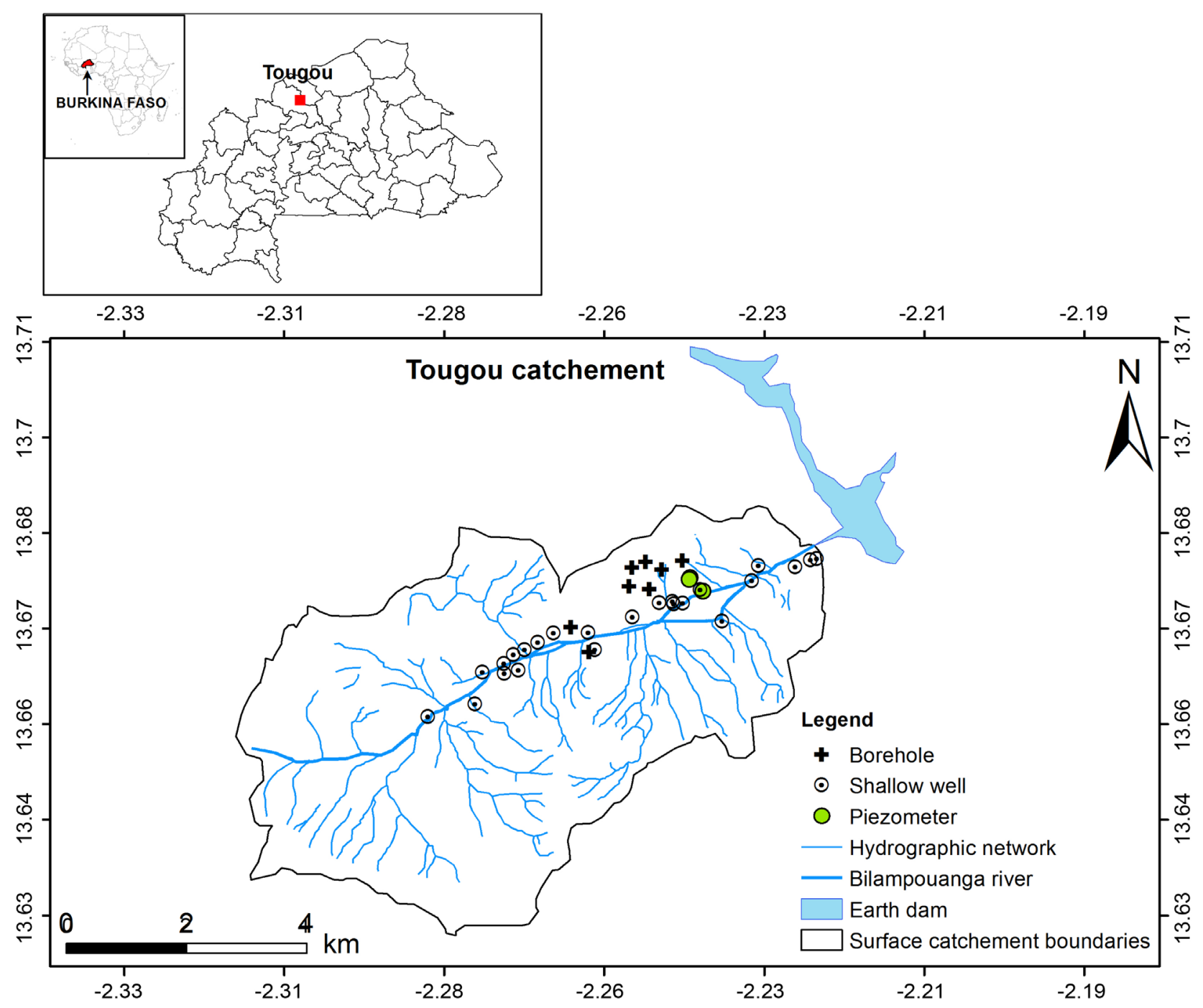

Figure 1. Location of the Tougou catchment in Burkina Faso, showing the extent and locations of the river, boreholes, shallow wells, and piezometers within the surface catchment.

along the rivers [11], the agroforestry area comprises the following plant species: Diospyros mespiliformis, Bauhinia reticulata, Balanitès aegyptiaca, ficus gna- 
phalocarpa, Tamarindus Indica, and Mitragyna inermis.

On the socio-economic level, the people of the Tougou region mainly practice mixed agriculture. Arable agriculture is predominantly rainfed and only practiced during the wet season with millet and sorghum the main crops. The rest of the year is devoted to livestock and irrigated farming at the outlet of the catchment around the dam.

The geology of the catchment consists of schist patchwork and green rocks. The schists complex of are sedimentary origin and metamorphosed around 2000 mya [12]. They consisted of various sandstones and epimetamorphic schists, almost exclusively represented by schists and sandstones more or less pelitic, to which were added manganiferous soil layers and very incidentally graphite layers. As a result of their profound alteration, these rocks take on aspects of shales or clayey sandstones of various colors. Green rocks are intrusive basic lavas (gabbro, andesite) that have been caught in folds and metamorphosed. They are present in the form of volcanic tuffs intersected by large bands of volcanic tuffs that are schistious basement. In NE-SW-oriented schist and quartzite hills, the rocks appear in the form of tips oriented in NE-SW direction. According to IWACO [13], the weathering profile of the catchment (Figure 2) is generally made of the following layers from top to bottom:

- A lateritic cuirass layer in some parts of the catchment which appears pitted and hardened on the ridges while in the valley bottom, the layer contains large quantities of water. The layer has an average thickness of $6 \mathrm{~m}$ with $10 \mathrm{~m}$ on top of the ridges. This concretionary breastplate is due to a diagenetic differentiation. It contains ferruginous nodules of a dark brown red color. The matrix consisting of red-brown or yellow clay contains empty lines due to plant roots;

- A light brown yellow layer of clay alteration containing subhorizontal, conjugated and subvertical diaclases. The thickness varies from one place to another with an average of $30 \mathrm{~m}$;

- A transition zone between the clay alteration layer and the bedrock made up of clayey alteration locally more consistent. The altered rock is kaolinitised around the diacases;

- The bottom of the profile consists of schists. The diaclases are well developed with dyke fillings of calcite and quartz. The unweathered rock is characterized by voids created by the dissolution of calcite contained in the quartz-calciteous veins. These different layers thus constitute the main reservoirs on the catchment.

On hydrogeological consideration, each of the described compartments of the weathering profile forms an aquifer. As a result, three types of hydraulically interconnected aquifers are superimposed: 1) the lateritic cuirass aquifer, 2) the clay alteration aquifer, and 3) the transition zone-a fractured unweathered schist complex saturated at the mid-slope and the valley-bottom where hand-dug wells provide water for animals. The lateritic cuirass at hills and mounds is made 


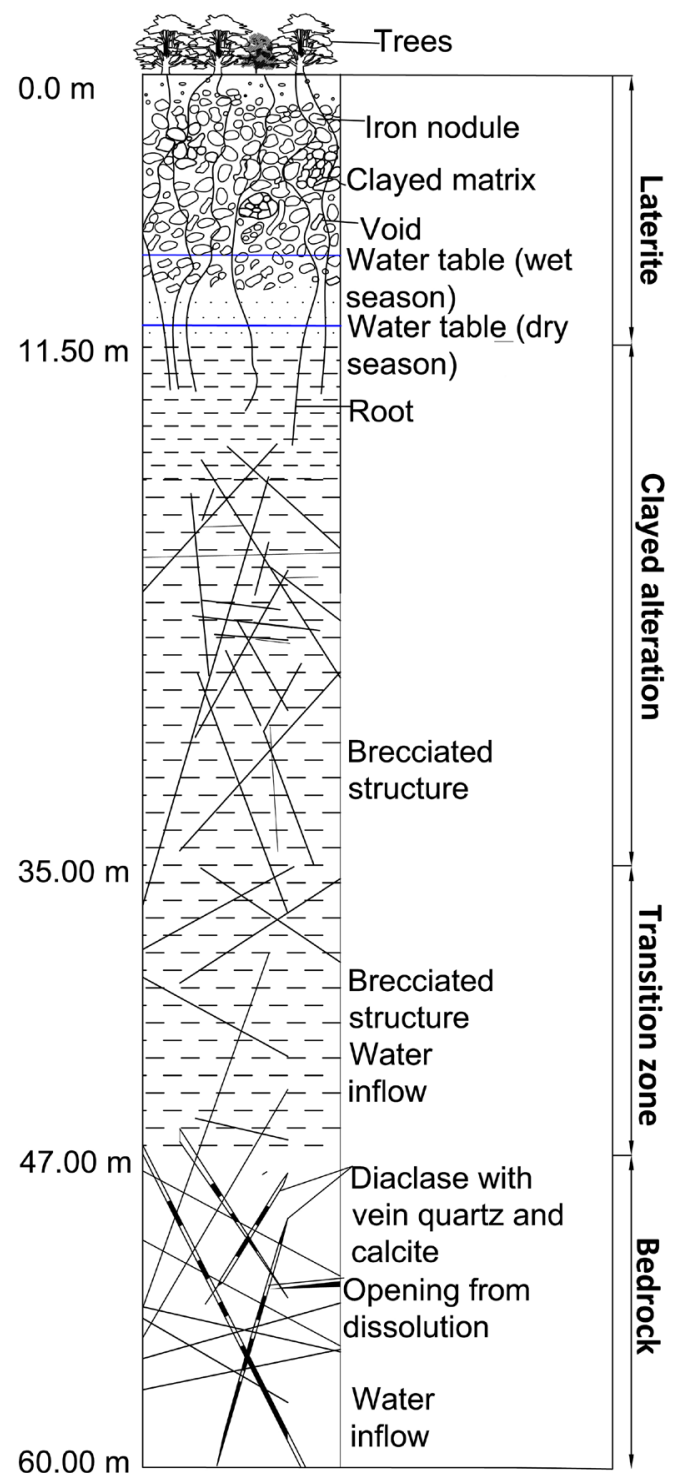

Figure 2. Weathering profile of Tougou catchment with average thickness of the layers.

of a hardened carapace on the top which is more favorable to runoff than infiltration. The clay alteration aquifer contains a lot of water but is very unproductive due to its low permeability. The aquifer of the transition zone-fractured unweathered schist complex represents the main reservoir because of its great hydraulic capacity. This deep system is recharged both by slow infiltration through piston effect from the saturated alteration and by rapid localized infiltration from the upper horizons.

Water level in these aquifers in wet periods varies between 8 and $11 \mathrm{~m}$ from soil surface. Whatever the season, the water level never falls below $12 \mathrm{~m}$ and thus, always remains in the clay alteration layer. This shallow water table favors phreatic withdrawal for transpiration by large trees that colonize the catchment slope and valley-bottom with their roots going up to ten meters and even more. 


\section{Material and Methods}

The Tougou experimental site will be described in this section using the presentation of the piezometers installed in order to have a better understanding of the water table fluctuation (WTF) in each layer of the weathering profile. Methods used to characterize WTF and estimate recharge will also be described. The estimated recharge at the catchment scale will be used in the water balance equation to infer actual evapotranspiration; a parameter not often estimated in Sahelian climates.

\subsection{Tougou Experimental Site}

The Tougou experimental site consists of three groups of piezometers called A, B and C (Figure 3). They are located at different positions in the catchment: at the mid-slope and the valley-bottom. This design mainly aims to: 1) understand vertical and lateral water exchange mechanisms and 2) estimate groundwater recharge at the catchment scale.

Piezometers groups A and B were drilled on the mid-slope of the left riverside at $30 \mathrm{~m}$ distance between each other. Piezometers of group A are composed of a

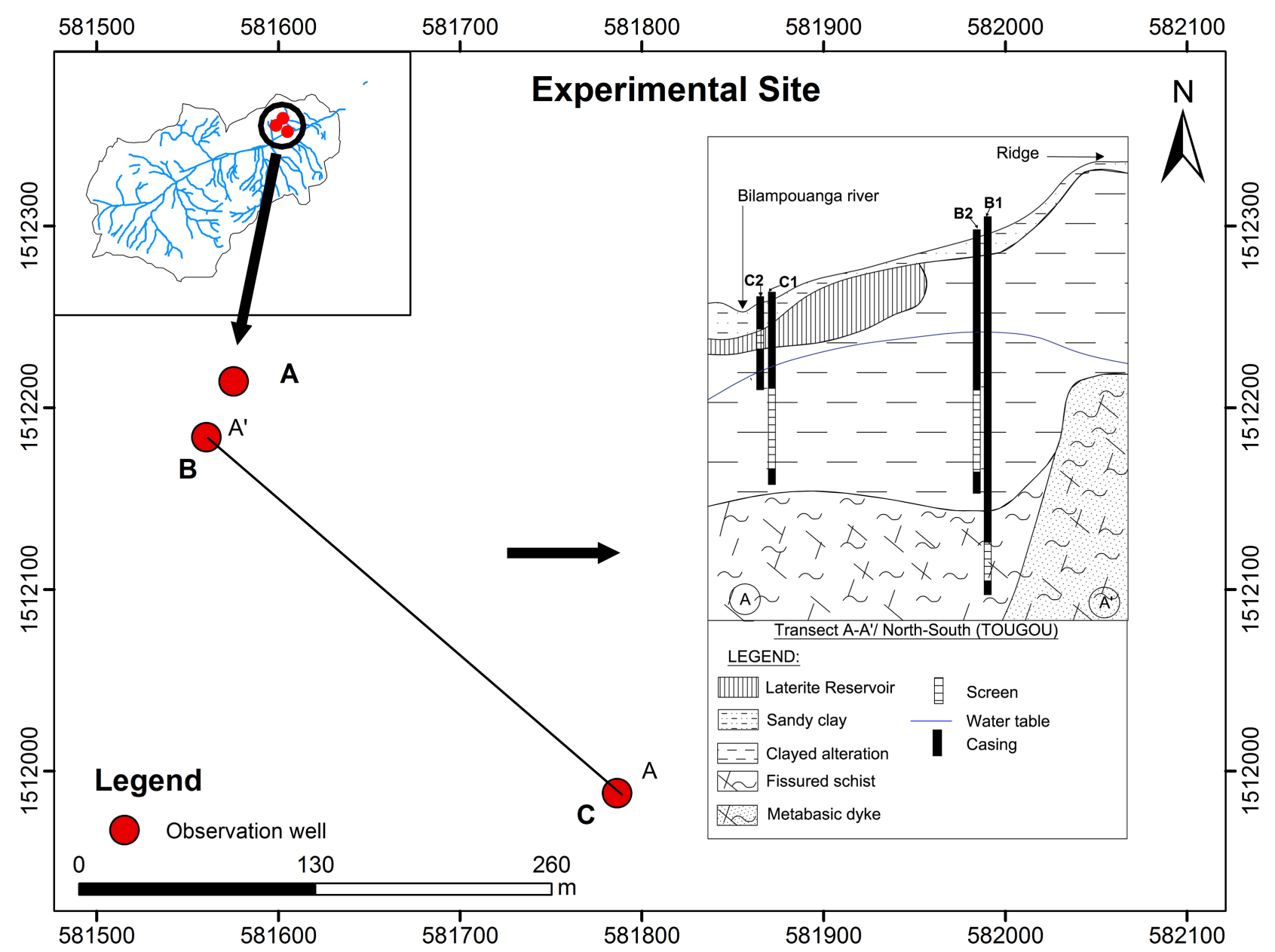

Figure 3. Location and design of piezometers cluster on Tougou experimental site (modified from IWACO [13]). 
deep borehole completed in the transition zone-fractured unweathered schist complex. Group B is made up of two piezometers B1 and B2 drilled close to each other and taping the transition zone-fractured unweathered schist and the clay alteration layer, respectively. The group $\mathrm{C}$ piezometers are in the valley-bottom. They are made of two piezometers $\mathrm{C} 1$ and $\mathrm{C} 2$ closely drilled and taping clay alteration aquifer and lateritic cuirass, respectively. Piezometers of this part of the site have undergone differential levelling for their altimetry characteristics indispensable in determining vertical and lateral water exchanges mechanisms.

\subsection{Recharge Estimation}

Various methods in aquifer recharge estimation exist. Most of them are tributary to specific recharge mechanism, climate conditions. The WTF method among others is seen to be one of the most used methods [14] for its independence from climate conditions [15]. The methods popularity comes from its straightforward use and the general availability of water table data for recharge estimation [7]. The WTF method is based on the hypothesis that any water table rise in unconfined aquifer is due to recharge [16]. The employed methodology is based on applying the WTF method in conjunction with the groundwater budget method developed by Marechal et al. [8]. The WTF method allows estimating change in groundwater storage based on water level fluctuation (Equation (1)).

$$
\Delta S=S_{y} * \Delta h
$$

where $\Delta S$ is change in groundwater storage; $S_{y}$ is specific yield or the quantity of water that could drain from an aquifer by the gravity force; $\Delta h$ is water level fluctuation.

The change in groundwater storage can be attributed to recharge, irrigation return flow and groundwater inflow to the catchment minus baseflow (groundwater discharge to streams or springs), evapotranspiration from groundwater, pumping, and ground water outflow from the catchment. The water balance equation (Equation (2)) is considered to be [17]:

$$
R+R F+Q_{o n}=E T+P G+Q_{o f f}+Q_{b f}+\Delta S
$$

where $R$ is the amount of total groundwater recharge (sum of the direct recharge $\left(R_{d}\right)$ from the precipitation and the indirect recharge $\left(R_{i j}\right)$ from surface bodies), $R F$ is the irrigation return flow, $Q_{o n}$ and $Q_{o f f}$ are respectively the input and output groundwater flows, $E T$ is the evapotranspiration from the ground water, $P G$ signifies the pumping from the aquifer, $Q_{b f}$ is the baseflow (i.e. springs, Qanats and baseflow to the surface bodies such as rivers and lakes) and $\Delta S$ represents the changes in groundwater storage. Substitution of Equation (1) into Equation (2)

$$
R+R F+Q_{o n}=E T+P G+Q_{o f f}+Q_{b f}+S_{y} \Delta h
$$

In the actual study each of the Equation (3) parameters has been determined in the Tougou catchment environment. The following are the various methods used to estimate Equation (3) parameters: 
- $S_{y}$ is considered representing the volume of water released per unit area of an aquifer due to unit loss in hydraulic head [18]. Accurate estimation of this parameter is crucial in reasonable recharge evaluation. Many methods exist in estimating specific yield such as laboratory tests, grain size analysis or pumping tests. In this study, $S_{y}$ is obtained by applying the water budget method presented by Healy and Cook [14]. This method is based on solving Equation (3) for the dry season period where $R=0$; thus Equation (4) is derived. During dry-season period, recharge from precipitation is approximately equal to zero partly due to very small precipitation, high temperature, and very dry climatic conditions.

$$
S_{y}=\frac{R F^{d r y}+Q_{o n}^{d r y}-E T^{d r y}-P G^{d r y}-Q_{o f f}^{d r y}-Q_{b f}}{\Delta h^{d r y}}
$$

- The recharge $R$ is estimated when solving Equation (3) in wet season period following $S_{y}$ determination; then Equation (5).

$$
R=\Delta h^{\text {wet }} * S_{y}-R F^{\text {wet }}-Q_{o n}^{\text {wet }}+E T^{\text {wet }}+P G^{\text {wet }}+Q_{\text {off }}^{\text {wet }}+Q_{b f}
$$

The WTF $\Delta h$ is estimated from hydraulic head measurements from piezometers at mid-slope and valley-bottom of the experimental site which are not influenced by water abstractions from pumping boreholes. $\Delta h$ determination in the WTF method is complex. Indeed, despite the assertion on which the method is relied on, not all water table rises in aquifers are attributable to infiltrated water from rainfall [14]. Various phenomenon that are independent from rainfall, can induce water table rise. Examples are given by entrapped air in pores, ocean tides and the earth's crust deformations, and variation in atmospheric pressure [19]. Daily monitoring of piezometers in the Tougou experimental site between 2010 and 2015 provided data for drawing groundwater hydrographs. Hydrographs interpretation helped in $\Delta h$ determination during dry and wet seasons (Figure 4). For $\Delta h$ determination in the dry season (Equation (4)), only $\Delta h$ values one month after the water table rise were considered in order to obtain true WTF for a storage corresponding to the specific yield value. This consideration is based on Marechal et al. [8], who assumed the time interval of one month to be enough for entrapped air in the aquifer to be evacuated.

\section{- Pumping rate}

Over the Tougou catchment, eight boreholes equipped with hand pumps and 24 shallow wells exist. Most of the boreholes are located in the center of Tougou village and supply domestic water needs (drink, bath, kitchen, laundry) of the population. Wells are generally drilled in the valley bottom where the water table is shallow and water is withdrawn using buckets. Water from wells is mostly intended for watering livestock in the dry season because animals drink in small depressions which collect runoff around the main river during wet season. There are no crops irrigated with groundwater in the catchment; therefore water taken from the catchment aquifers is used only to supply the populations and livestock. In order to know the water quantity taken from the aquifers for domestic 
$\mathrm{C}$

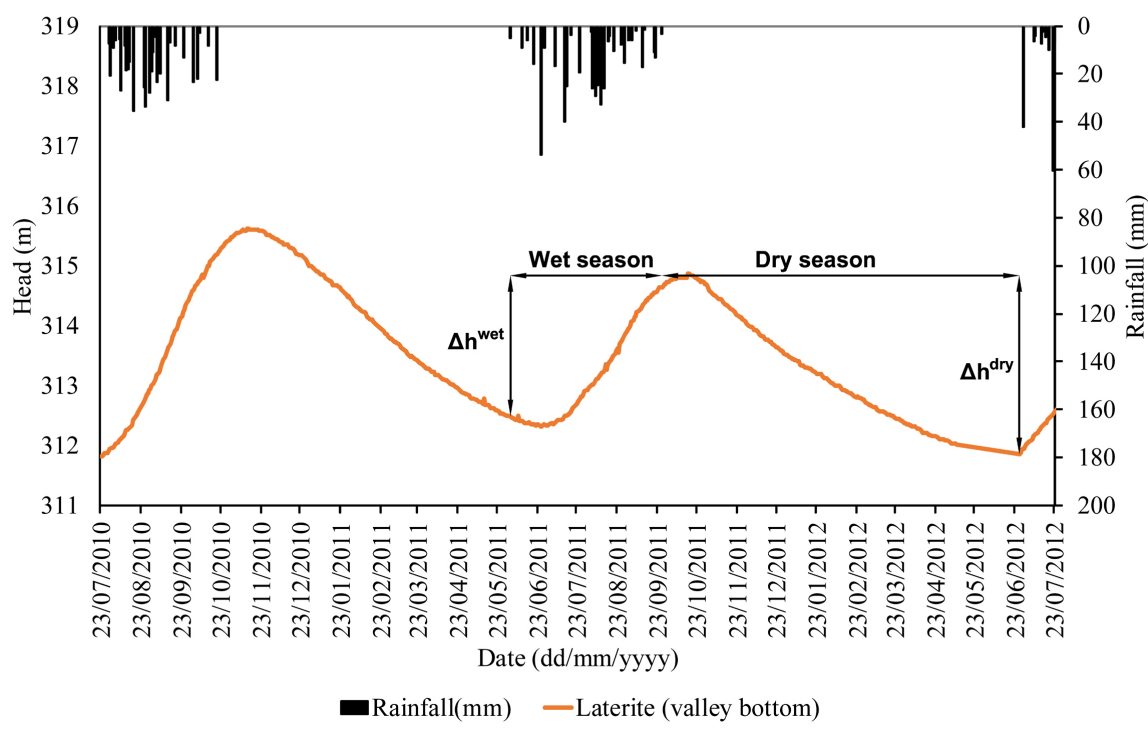

Figure 4. Groundwater hydrograph observed in lateritic cuirass at the valley bottom showing seasonal water fluctuation.

purposes, household surveys were conducted. These surveys show that per capita consumption was about 19.32 liters/day. The population growth rate in the village given by INSD [20] is $2.7 \%$ for a population estimated at 4666 inhabitants in 2006. Based on these population data, extrapolation provided figure of the village population size between 2010 and 2015 to infer their water demands. Additionally, water losses during the filling of the containers and their transport were estimated at $5 \%$ of water demands. The sum of estimated use and losses gives the total quantity of water taken from the aquifer through boreholes equipped with hand pumps.

Following this estimation, water quantities for livestock through wells, have been evaluated based on the number of cows, goats, sheep and cattle that make up the bulk of the livestock and the specific water consumption of each species. For the specific consumption of livestock species, reference was made to the values given in Meyer [21]. The total water quantity withdrawn from the catchment for watering livestock was limited only to the dry season period of November to June, as during the wet season animals drink from small reservoirs.

- ET

Actual evapotranspiration (ET) has been taken into account in the Tougou catchment because groundwater is shallow, therefore partly evaporated. It was computed by water balance at the catchment scale. ET was estimated using Equation 6 from Coudrain et al. [22]:

$$
q=71.9 x z^{-1.49}
$$

where $q$ is evaporative flux ( $\mathrm{mm} /$ year) and $z$ is the piezometric depth (m).

The presence of big trees on the catchment slopes and the valley bottom has induced consideration on their evapotranspiration taken to be $20 \mathrm{~mm}$ per year 
in reference to Tolma [23] and Ouedraogo [24] whose works on the Tougou catchment provided such figure.

$\mathrm{RF}$ was taken to be zero as no irrigation cropping is practiced on the catchment.

$Q_{b f}$ values are also considered zero as groundwater discharge to surface water, $Q_{b i}$ via river discharge or springs does not exist.

inflow $\left(Q_{o n}\right)$ and out-flow $\left(Q_{o u t}\right)$ values are considered nil for the fact that aquifers within the research site are in flat hard-rock with the regional water table being sub-parallel to the regional topography; therefore groundwater flows through the boundaries of the surface catchment being negligible [8] [25].

Given the previous assumptions and considerations, the equations used for estimating specific yield $S_{y}$ and groundwater recharge $R$ are simplified to Equations (7) and (8), respectively:

$$
\begin{gathered}
S_{y}=\frac{-E T^{d r y}-P G^{d r y}}{\Delta h^{d r y}} \\
R=\Delta h^{\text {wet }} * S_{y}+E T^{\text {wet }}+P G^{\text {wet }}
\end{gathered}
$$

Since the components of the two equations are estimated at the catchment scale, recharge is also determined at the same scale.

\subsection{Estimation of Evapotranspiration}

It is always difficult to accurately estimate groundwater recharge using one method as every method relies on assumptions that induce uncertainty on the results; hence Healy and Cook [14] suggest using multiple methods. Therefore, the long-term data series (runoff, rainfall, infiltration, etc.) collected at the catchment scale will be of great contribution. Indeed, the monitoring made it possible to establish a water balance at the catchment scale based on the law of mass conservation according to which the sum of the contributions equals that of losses plus or minus change in the catchment water storage as translated into equation (Equation (9)).

$$
\text { Inputs }=\text { Losses } \pm \Delta S
$$

On Tougou experimental site, Inputs are limited to rainfall only and losses, the sum of actual evapotranspiration $(E T R)$, runoff $(R)$ and infiltration $(I)$ which gives Equation (10) as followed:

$$
P=I+E T R+R \pm \Delta S
$$

with:

P. Precipitation $(\mathrm{mm})$; derived from 5 rainfall stations installed over the whole Tougou catchment according to spatial variability in rainfall within the site;

I: Infiltration (mm); this parameter is considered equal to recharge estimated with the WTF method;

$R$ : runoff (mm); gauging and permanent runoff heights measurements at the catchment outlet provided estimation of the parameter for the study catchment;

$\Delta S$ : change in the catchment water storage; this parameter is considered zero 
over a long period;

Since actual evapotranspiration is one of the most complex terms of the water balance to estimate [26], this parameter will be determined using water balance method. In order to validate the estimated result of actual evapotranspiration from Equation (10), comparisons will be done with values from different studies over the Tougou catchment and surrounding areas with similar climate conditions.

\section{Results and Discussions}

\subsection{Water Table Fluctuation}

\subsubsection{Rainfall-Water Level Fluctuation}

Piezometry and rainfall dynamics in the Tougou catchment between 2010 and 2015 show rainfall to be the only source of aquifer recharge once a year with a unique contribution from June to October and some peaks in July and August (Figure 5 and Figure 6). The water level rise and decline in the aquifer are under rainfall control. Therefore, water level rise occurs in the period from June to October and corresponds to the wet season; while water level decline corresponds to the dry season period from November to May. It was observed that the aquifer is not responding immediately to the onset of the wet season. A delay instead is observable in the groundwater response to daily precipitation; a delay which can vary from one year to another between 18 to 47 days. This delay

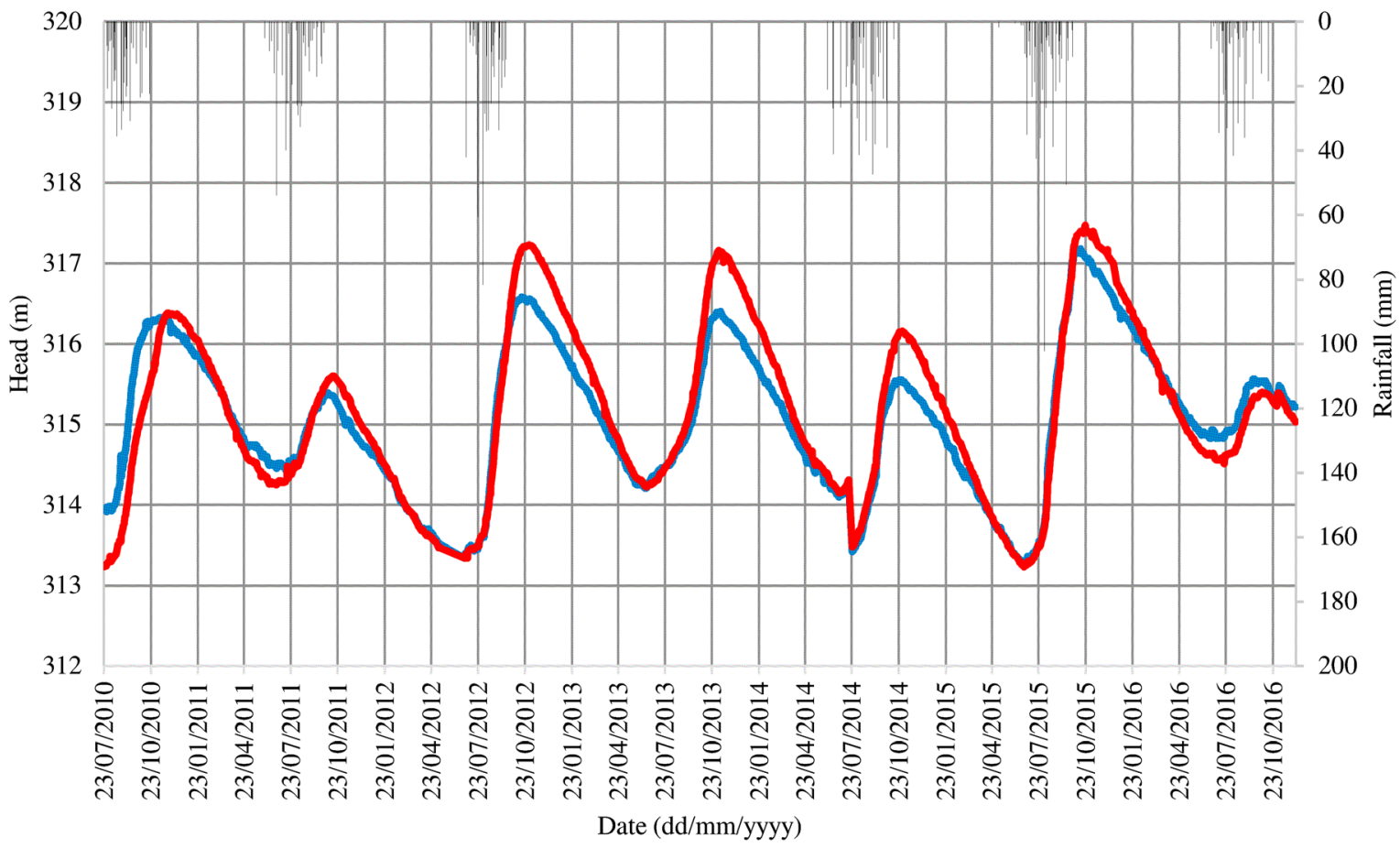

Rainfall (mm) $\longrightarrow$ Transition zone and fractured schist (Mid-slope) $\rightleftharpoons$ Clayey alteration (Mid-slope)

Figure 5. Groundwater hydrographs and bar graphs of daily rainfall in different layers of the weathering profile at mid-slope. 


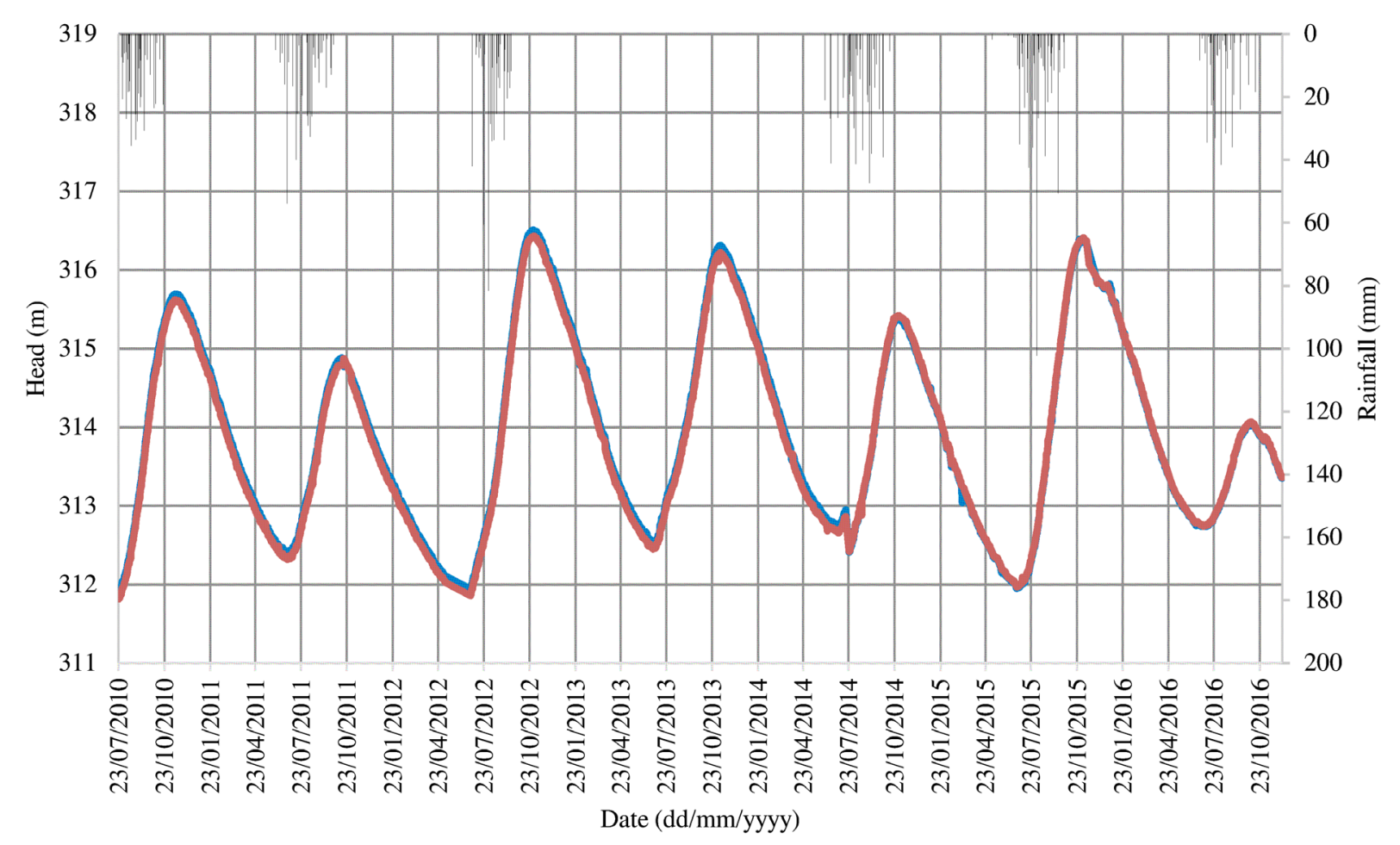

Rainfall $(\mathrm{mm}) \quad$ Clayey alteration (valley bottom $\quad$ Laterite (valley bottom)

Figure 6. Groundwater hydrographs and bar graphs of daily rainfall in different layers of the weathering profile in the valley bottom.

period; i.e. the time-lag, appears to correspond to the duration of top soil humidification from its drying during the preceding season. The delay in groundwater response to first rain events is simultaneously observable in all the piezometers irrespective of their location in the catchment and the aquifer concerned. Various parameters including rainfall depth, number of rain events, water table depth and rainfall spacing can explain the observed situation.

During the wet season, $\Delta h^{\text {wet }}$ is proportional to the preceding $\Delta h^{d r y}$. Indeed, when $\Delta h^{d r y}$ preceding the wet season is low, $\Delta h^{\text {wet }}$ is higher. During dry season, $\Delta h^{d r y}$ is highly correlated to the preceding $\Delta h^{\text {wet }}$. These findings suggest that $\Delta h^{\text {wet }}$ is not a function of total annual rainfall. Effectively, years 2012 and 2015 which recorded the lowest annual rainfall depth of the catchment data series depicted the highest $\Delta h^{\text {wet }}$ values ever. Moreover, it has been observed that the general trend of the piezometry is not decreasing despite the downward trend in rainfall under Sahel climate conditions [27]. In Southwest Niger under Sahelian climate, Favreau [28] in his research observed an increase in water table depth since 1950 to 1960 linked to runoff increase during the same period within the river catchment and explained by land encroachment. The observed equilibrium between two consecutive $\Delta h^{\text {wet }}$ and $\Delta h^{d r y}$ could suggest that no storage change occurs in the aquifers during a hydrological year. In addition, WTF in each of weathering profile layers show that $\Delta h^{d r y}\left(3.4 \mathrm{~m}\right.$ on average) and $\Delta h^{\text {wet }}$ are much 
varying in the valley bottom (between 2.5 to $4.5 \mathrm{~m}$ ) than in mid-slope (between 1 to $4 \mathrm{~m}$ ).

Joint analysis of rainfall data and aquifer response revealed that only the spacing between rainfall events and the average rainfall amount per rain event were significantly correlated with the aquifer response. Indeed, the shorter the spacing between rain events, the faster the aquifer response as short rain events spacing left subsequent rains with much wetted soil nearly saturated thus favoring deep drainage that can reach the water table. Comparing the response times of the aquifer in consecutive years 2011-2012 and 2014-2015, the following are observed:

- For the period 2011-2012; year 2011 shows the shortest aquifer response time due to the temporal frequent occurrence of the rain events despite the quantities of average rain per event almost identical in the two years;

- For the period 2014-2015; observations show year 2015 to have the highest average rainfall amount per event of $30 \mathrm{~mm}$. while the aquifer response time is identical to that of 2014, a lower average rain event amount of $21.73 \mathrm{~mm}$ was recorded in 2014. This situation could be explained by the spacing between the rain events that is shorter for the year 2014.

\subsubsection{Vertical Water Exchange}

The determination of the exchange mechanisms between the different layers of the aquifer alteration profile is based on interpretation of their piezometric fluctuation curves over the period 2010-2016:

- At valley-bottom

Water table variations in the lateritic cuirass and the clayey alteration layer are almost similar, resulting into superimposition of the two groundwater hydrographs (Figure 5). Thus, both layers show a good hydraulic connection which allows them to remain in balance with the seasons. Indeed, this connection favors an exchange of water flux between the two reservoirs making it possible to restore imbalance (pumping, evapotranspiration, recharging, etc.) created in one or other of the reservoirs.

\section{- At mid-slope}

Unlike the behavior observed in the lateritic cuirass and the clayey alteration layer at the valley bottom, clayey alteration and the transition zone-fractured unweathered schist at the mid-slope have no similarity in their piezometry data at any time of the year (Figure 4). In high water periods, water level peak in alteration and in the fractured medium are slightly offset in time: the maximum of water level is reached first in the transition zone-fractured unweathered schist complex and then in the alteration. Subsequently, the observed water recharge of the transition zone-fractured unweathered schist complex remained lower than that in the alteration during the period of water level decline until March and April. In general, the periods of water level rise and decline in the two layers are similar; except for the years 2011 and 2016 with low water level rise where recharge in the transition zone-fractured unweathered schist complex was higher 
than that of clayey alteration at the end of the period of water level decline and beginning of water level rise. The hydraulic head increase in the superficial altered layer with respect to the underlying transition zone-fractured unweathered schist complex probably due to the difference in drainage porosity between the two reservoirs. Indeed, the drainage porosity in the clayey alteration layer would be low given its very clay tendency compared to that of the transition zone-fractured unweathered schist complex dominated by brecciated structures. This situation has a limiting effect on the exchange flow between the two media. During high rainfall period of middle of the wet season, the water flow reaching the clay alteration layer is too great to be fully transmitted to the transition zone-fractured unweathered schist complex. This water transfer therefore takes place slowly until a balance is reached when tending towards the end of the dry season.

\subsubsection{Water Exchange Mechanisms}

Analysis of groundwater hydrograph of the clay alteration layer recorded in the mid-slope and in the valley bottom shows an identical behavior characterized by parallel curves and simultaneous peaks (Figure 7). This shows a quite good lateral hydraulic connection in the clay alteration. In addition, hydraulic head at mid-slope is always higher than that in the valley-bottom. This may suggest that the valley bottom is a preferential drainage area, contrary to the assumption

Clayey alteration

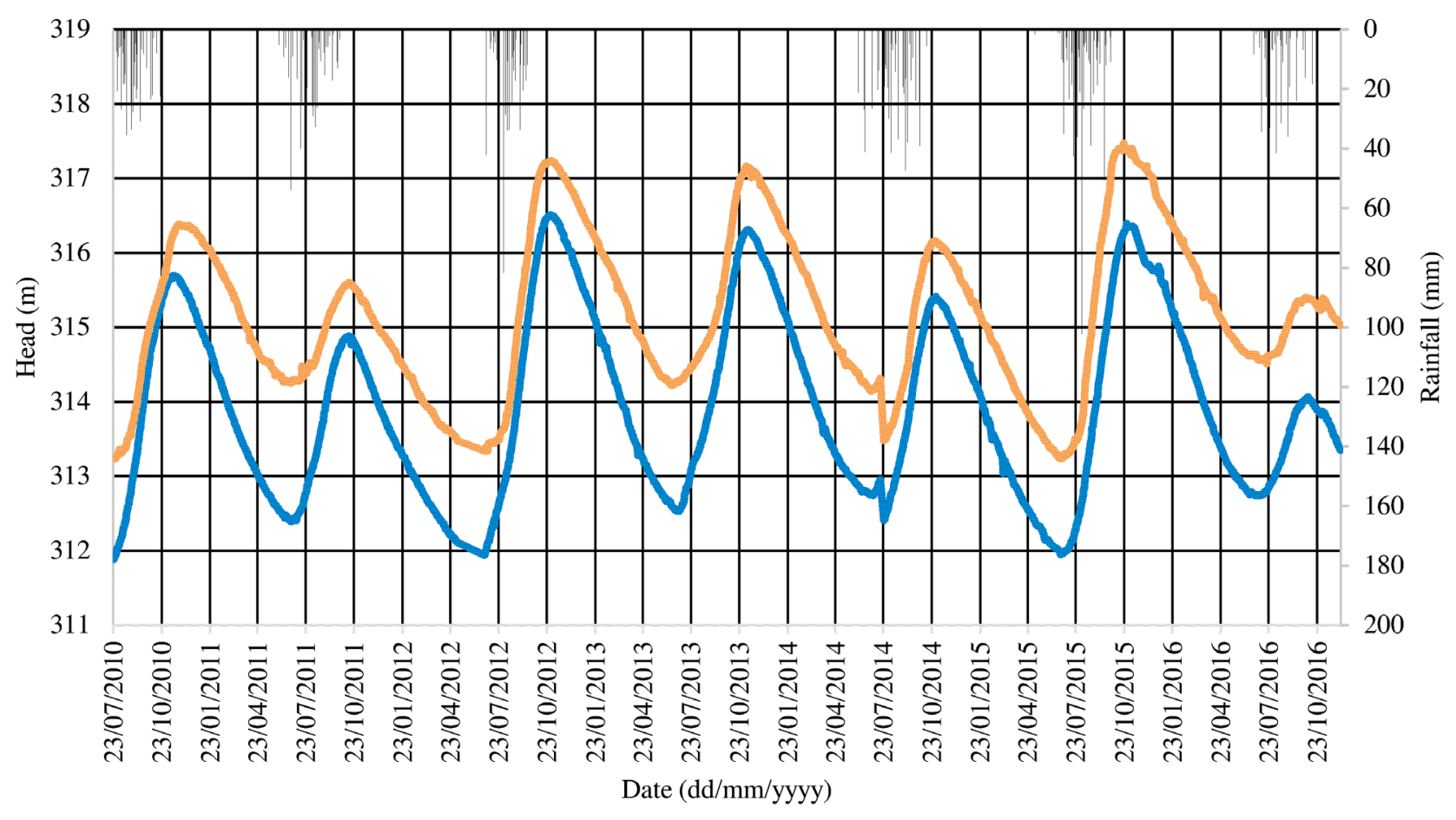

Figure 7. Groundwater hydrographs and bar graphs of daily rainfall observed in alteration in the valley bottom and at mid-slope. 
made by previous work of IWACO [13] showing the valley bottom to be a preferential recharge zone. Can high amplitudes of WTF observed during the periods of water level rise and decline at the valley-bottom suggest that the latter is both a preferential recharge and discharge zone? Investigations carried out at this stage do not provide any clear answer. It appears therefore necessary to realize a piezometer transect between the two valley banks through the valley bottom in addition to investigations with natural tracers (electrical conductivity and/or water temperature monitoring).

\subsection{Specific Yield Estimation}

The drainage porosity or specific yield values at the catchment scale vary between 0.006 and 0.009 (Table 1), depending on the year. This variation is due to WTF which varies according to the type of rainy years of surplus or deficit. The porosity of drainage and $\Delta h$ (dry season) are varying inversely. Indeed, the water table is located in clayey alteration whatever the season. When the saturated thickness of the clay alteration is significant (increasing $\Delta h$ ), the drainage porosity decreases, which means that the drainage porosity of the clay alteration would be lower than that of the underlying layer of the weathering profile. This result is in agreement with the structure of the weathering profile which shows a very clayey upper part which does not favor good drainage and a lower part of brecciated structures with many interconnected voids favorable to drainage. In the granite area, the inverse behavior is observed with drainage porosity decreasing with depth [29]. Indeed, in this type of environment, the alteration is of arenitic type with sandy-clay tendency favorable to drainage and the fracturing density decreases with depth. The drainage porosity values obtained at Tougou are of the same order of magnitude as those on similar formations in arid zones [30]. On other hand, these porosity values are very low compared to drainage porosity obtained by IWACO [13] through pumping tests on the same catchment. The values were varying from 0.005 to 0.06 ; the differences in porosity value obtained using water balance method and pumping test appear to be normal. In fact, the specific yield, when estimates directly from pumping tests, involves some errors which come from the aquifer stratification, slow drainage of materials (i.e. delayed water) and air entrapped near the water table [8] [9]. According to Rezaei and Mohammadi [9], specific yield calculated with WTF

Table 1. Groundwater budget and values of specific yield from 2010 to 2015.

\begin{tabular}{ccccccc}
\hline $\begin{array}{c}\text { Hydrological } \\
\text { year }\end{array}$ & $R F^{d r y}(\mathrm{~mm})$ & $\begin{array}{c}P G^{d r y} \\
(\mathrm{~mm})\end{array}$ & $\begin{array}{c}E T^{d r y} \\
(\mathrm{~mm})\end{array}$ & $\begin{array}{c}Q_{o n}-Q_{o f f} \\
(\mathrm{~mm})\end{array}$ & $\Delta h^{d r y}(\mathrm{~m})$ & $S_{y}$ \\
\hline $\mathbf{2 0 1 0 - 2 0 1 1}$ & 0 & -1.34 & -21.45 & 0 & -3.03 & 0.0075 \\
$\mathbf{2 0 1 1 - 2 0 1 2}$ & 0 & -1.36 & -21.37 & 0 & -2.52 & 0.0090 \\
$\mathbf{2 0 1 2 - 2 0 1 3}$ & 0 & -1.38 & -21.42 & 0 & -2.92 & 0.0078 \\
$\mathbf{2 0 1 3 - 2 0 1 4}$ & 0 & -1.40 & -21.49 & 0 & -3.41 & 0.0067 \\
$\mathbf{2 0 1 4 - 2 0 1 5}$ & 0 & -1.42 & -21.39 & 0 & -3.45 & 0.0066 \\
\hline
\end{tabular}


method practically has a smaller error since the delayed water has a long-enough time to go several meters distance (even in fine grain sediments having low hydraulic conductivity). Specific yield is only estimated based on the water level decline over the dry period; therefore smaller quantities of entrapped air in soil pores since air entrapping usually occurs during water level rising and not during the declining period.

\subsection{Recharge Estimation}

Characterizing vertical water exchange mechanisms has made it possible to determine that the layers which directly receive water from the recharge were clayey alteration and lateritic cuirass. However, because the lateritic cuirass does not exist throughout the catchment, the recharge quantification using the WTF method is based solely on WTF recorded in the clayey alteration layer. The recharge values obtained at the catchment scale during the study period is shown in Table 2. The groundwater budget reveals that groundwater abstractions through pumping and evaporation are very low with an average of $0.35 \mathrm{~mm}$ and $0.7 \mathrm{~mm}$ respectively. The major part of the groundwater withdrawal is ensured by tree transpiration at mid-slope and the valley-bottom.

The Tougou catchment recharge estimate compared to other values from IWACO [13] using various methods on the same Tougou catchment revealed the estimates to be almost identical to that of tritium balance method $(38 \mathrm{~mm})$. However, the estimated value is slightly higher than those from water balance (20 to $30 \mathrm{~mm}$ ) and chloride balance methods (about $25 \mathrm{~mm}$ ). The recharge coefficient $(\mathrm{R} / \mathrm{P})$ from the actual estimates varies between 6\% and 9\%. From 1990 (first recharge estimations period by IWACO [13] till now, the Tougou catchment recharge values did not seem to decrease despite annual rainfall decline observed in the Sahelian zone. Groundwater resources seem to be therefore less influenced by climate effects. But it could also be more likely that the so-called soil and water conservation practices developed in the Tougou catchment to combat soil degradation [31] [32] [33] have been improved groundwater recharge processes in the catchment. These practices would have probably increased soil infiltration, resulting into deep drainage to the water table [34]. In general, groundwater recharge values in the Tougou catchment are within the range of recharge values obtained in several zones of West Africa [16]

Table 2. Water balance of the Tougou catchment and recharge estimation from 2010 to 2015.

\begin{tabular}{cccccccc}
\hline $\begin{array}{c}\text { Hydrological } \\
\text { year }\end{array}$ & $S_{y}$ & $P G^{\text {wet }}(\mathrm{mm})$ & $E T^{\text {wet }}(\mathrm{mm})$ & $\Delta \boldsymbol{h}^{\text {wet }}(\mathrm{m})$ & $R(\mathrm{~mm})$ & $\boldsymbol{P}(\mathrm{mm})$ & $R / P(\%)$ \\
\hline $\mathbf{2 0 1 0 - 2 0 1 1}$ & 0.0075 & 0.33 & 20.73 & 2.29 & 38.3 & 449.3 & 9 \\
$\mathbf{2 0 1 1 - 2 0 1 2}$ & 0.0090 & 0.34 & 20.69 & 3.19 & 49.8 & 697.7 & 7 \\
$\mathbf{2 0 1 2 - 2 0 1 3}$ & 0.0078 & 0.35 & 20.71 & - & - & - & - \\
$\mathbf{2 0 1 3 - 2 0 1 4}$ & 0.0067 & 0.36 & 20.74 & 2.4 & 37.2 & 624.3 & 6 \\
$\mathbf{2 0 1 4 - 2 0 1 5}$ & 0.0066 & 0.37 & 20.70 & 2.36 & 36.7 & 645.24 & 6 \\
\hline
\end{tabular}


[35] [36] [37] and elsewhere with similar geological formation and climate conditions [30]. The integration of these recharge values into the balance sheet equation value of actual evapotranspiration (Table 3 ).

Actual evapotranspiration in the Tougou catchment varies between 323 and $443 \mathrm{~mm}$. These values are higher than those of Sompougdou [38] who estimated $343 \mathrm{~mm}$ in 2004 and $350 \mathrm{~mm}$ in 2005 for the same Tougou catchment. On the other hand, these values are in agreement with the results of Niang [39] who estimated the catchment ETR between 1 and $2 \mathrm{~mm}$ per day.

\section{Conclusions}

The analysis of the WTFs in different aquifers of the Tougou catchment showed that recharge is mainly due to rainfall during the wet period (from June to October). The trends of WTF in the different layers of the weathering profile are similar. There is a time-lag response of groundwater recharge to the daily precipitation occurrences. The magnitude of the recharge depends on the average amount of rain events and the spacing between them. In general, piezometry does not show a downward trend with regard to the decreasing rainfall trend in the catchment.

On vertical interaction between the saturated lateritic cuirass and the clayey alteration layer, the hydraulic heads in the two layers are balanced both during periods of water level rise and during periods of discharge. On the other hand, the interaction between the clayey alteration layer and the transition zone-fractured unweathered schist shows that in general the hydraulic head in clayey alteration layer is higher than that of the transition zone-fractured unweathered schist complex as soon as water level reaches its maximum till April or May period. Apart from this period, the hydraulic heads in the two layers remain in balance for the rest of the time.

On lateral water exchange, hydraulic head at mid-slope is higher than that recorded at the valley-bottom regardless of the period of the year. The valley-bottom would then represent a preferential discharge zone.

The drainage porosity at the catchment scale is estimated between 0.006 and 0.009 and is influenced by the saturated thickness of the clayey alteration layer of the weathering profile. These porosity values are well below those obtained from pumping tests. The recharge value was estimated between 36 and $49 \mathrm{~mm}$ per year, which would represent $6 \%$ to $9 \%$ of the average annual rainfall. Actual evapotranspiration is estimated at 300 and $350 \mathrm{~mm}$ per year.

Table 3. Actual evapotranspiration estimated based on water balance equation.

\begin{tabular}{ccccc}
\hline Year & Rainfall $(\mathrm{mm})$ & $R(\mathrm{~mm})$ & $I(\mathrm{~mm})$ & $E T R(\mathrm{~mm})$ \\
\hline 2011 & 4493 & 8806 & 38.3 & 323 \\
2012 & 6977 & 20,443 & 49.8 & 443.5 \\
2014 & 6243 & 18,417 & 37.2 & 402.9 \\
\hline
\end{tabular}


Despite the fact that the valley-bottom recorded high amplitudes of WTF during dry and wet season, the research could not confirm the hypothesis that the valley bottom could be a preferential recharge zone. To do this, a suggestion is to carry out additional investigations using piezometers transect going from the right bank to the left bank through the minor bed of the river. In addition to the previous, suggested parameters to monitor are electrical conductivity and water temperature in order to better understand groundwater recharge processes in the Tougou catchment.

\section{References}

[1] UNEP (2008) Africa: Atlas of Our Changing Environment. Division of Early Warming and Assessment (DEWA), Earth Resources Observation and Science, United States of America.

[2] N’go, Y.A., Goné, D.L., Savane, I. and Goblé, M.M. (2005) Potentialités en eaux souterraines des aquifères fissurés de la région d'Agboville (Sud Ouest de la Côte d'Ivoire): Caractérisation hydroclimatique et physique. [Potentialities in Groundwater of Fissured Aquifers in the Agboville Region (Southwestern Côte d'Ivoire): Hydroclimatic and Physical Characterization.] Afrique Science, 1, 127-144.

[3] Taylor, R.G., Kouassi, A.D. and Tindimugaya, C. (2009) Groundwater and Climate in Africa-A Review. Hydrological Sciences Journal, 54, 655-664. https://doi.org/10.1623/hysj.54.4.655

[4] Soro, D.D., Koïta, M., Biaou, C.A., Outoumbe, E., Vouillamoz, J.M., Yacouba, H. and Guérin, R. (2017) Geophysical Demonstration of Absence of Correlation between Lineaments and Hydrogeologically Useful Fractures: Case Study of Sanon Hard Rock Aquifer (Central-Northern Burkina Faso). Journal of African Earth Science, 19, 842-852. https://doi.org/10.1016/j.jafrearsci.2017.02.025

[5] Xu, Y. and Beekman, H.E. (2003) Groundwater Recharge Estimation in Southern Africa. Unesco IHPSeries Num 64, Paris, 3-16.

[6] Chand, R., Hodlur, G.K., Prakash, M.R., Mondal, N.C. and Singh, V.S. (2005) Reliable Natural Recharge Estimates In Granitic Terrain. Current Science, 88, 821-824.

[7] Obuobie, E., Bernd, D., William, A. and Sampson, A. (2012) Groundwater Level Monitoring and Recharge Estimation in the White Volta River Catchment of Ghana . Journal of African Earth Sciences, 71, 80-86. https://doi.org/10.1016/j.jafrearsci.2012.06.005

[8] Maréchal, J.C., Dewandel, B., Ahmed, S., Galeazzi, L. and Zaidi, F.K. (2006) Combined Estimation of Specific Yield and Natural Recharge in a Semi-Arid Groundwater Catchment with Irrigated Agriculture. Journal of Hydrology, 329, 281-293. https://doi.org/10.1016/j.jhydrol.2006.02.022

[9] Rezaei, A. and Mohammadi, Z. (2017) Annual Safe Groundwater Yield in a Semiarid Catchment Using Combination of Water Balance Equation and Water Table Fluctuation. Journal of African Earth Sciences, 134, 241-248. https://doi.org/10.1016/j.jafrearsci.2017.06.029

[10] Zoungranna, T. and Dior, T. (2009) Modélisation pluie-débit distrubuée-mise en oeuvre sur un catchment versant sahélien avec le logiciel ATHYS. Tougou/Burkina Faso. [Distributed Rain-Flow Modeling and Implementation on a Sahelian Watershed with ATHYS Software. Tougou/Burkina Faso.] Master Thesis, Polytechnique Montpellier, Montpellier.

[11] Kombe, W. (2011) Contribution des sites favorable a l'implantation des citernes 
d'irrigation de complement: Cas du catchment versant de Tougou au Burkina Faso. [Favorable Sites Contribution of Tanks Siting for Supplementary Irrigation; Case of the Watershed of Tougou (Burkina Faso).] Spéciaized Master Thesis, 2iE, Ouagadougou.

[12] Hottin, G. and Ouédraogo, O.F. (1975) Carte geologique de la Republique de Haute-volta 1:1 000 000. [Geological Map of the Republic of Haute-Volta 1: 1000 000.] Rép. de Haute-Volta. Ministère du commerce, du développement industriel et des mines, Direction de la géologie et des mines, Ouagadougou.

[13] IWACO (1990) Etudes du bilan d'eau au Burkina Faso. [Water Balance Studies in Burkina Faso.] Direction des etudes et de la planification (MINISTERE DE L'EAU), Burkina Faso.

[14] Healy, R.W. and Cook, P.G. (2002) Using Groundwater Levels to Estimate Recharge. Hydrogeology Journal, 10, 91-109.

https://doi.org/10.1007/s10040-001-0178-0

[15] Scanlon, B.R., Healy, R.W. and Cook, P.G. (2002) Choosing Appropriate Techniques for Quantifying Groundwater Recharge. Hydrogeology Journal, 10, 18-39. https://doi.org/10.1007/s10040-001-0176-2

[16] Cai, Z. and Ofterdinger, U. (2016) Analysis of Groundwater-Level Response to Rainfall and Estimation of Annual Recharge in Fractured Hard Rock Aquifers, NW Ireland. Journal of Hydrology, 535, 71-84. https://doi.org/10.1016/j.jhydrol.2016.01.066

[17] Schicht, R.J. and Walton, W.C. (1961) Hydrologic Budgets for Three Small Catchments in Illinois. Illinois State Water Survey, 40, 1-40.

[18] Freeze, R.A. and Cherry, J.A. (1979) Groundwater. Prentice Hall Inc., Englewood Cliffs, New Jersey, 36-38.

[19] Crosbie, R.S., Binning, P. and Kalma, J.D. (2005) A Time Series Approach to inferring Groundwater Recharge Using the Water Table Fluctuation Method. Water Resources Research, 41, 1-9. https://doi.org/10.1029/2004WR003077

[20] INSD (2006) Recensement general de la population et de l'habitation de 2006. [General Census of Population and Housing.] Ministère de l'économie et des finances, Bureau central du recensement, Ouagadougou.

[21] Meyer C., Ed. (2017) Dictionnaire des Sciences Animales. [Dictionary of Biological Sciences.] [On Line]. http://dico-sciences-animales.cirad.fr/

[22] Coudrain-Ribstein, A., Pratx, B., Talbi, A. and Jusserand, C. (1998) L'évaporation des nappes phréatiques sous climat aride est-elle indépendante de la nature du sol? [Is the Evaporation from Phreatic Aquifers in Arid Zones Independent of the Soil Characteristics?] Comptes Rendus de I Académie des Sciences Série 2a: Sciences de la Terre et des Planètes, 326, 159-165.

[23] Tolman, M. (1989) Transpiration des essences principals dans la période mars-mai 1989 dans quatre bassins versants représentatifs. [Transpiration of Main Species from March to May 1989 in Four Representative Watershed.] Report, Projet bilan d'eau, Ouagadougou.

[24] Ouedraogo, Y. and Koala, V. (1989) Consommation en eau de quelque espèces ligneuses au Burkina Faso. [Water Consumption of Some Woody Species in Burkina Faso.] Report, Projet bilan d'eau. Ouagadougou.

[25] Avenard, J.M., Eldin, M., Girard, G., Sircoulon, J., Touchebeuf, P., Guillaumet, J.L., and Adjanohoun, E. (1971) Le milieu naturel de la Côte d'Ivoire. [The Natural Environment of Ivory Coast.] Mémoire 50 ORSTORM, France. 
[26] El Garouni, A. (1995) Estimation et cartographie de l'évapotranspiration réelle par télédétection et systèmes d'Information Géographiques: Contribution à l'étude hydrogéologique de la basse vallée de la Medjerda. [Estimation and Mapping of Actual Evapotranspiration Using Remote Sensing Geographic Information Systems: Contribution to the Hydrogeological Study of the Low Valley of the Medjerda.] Ph.D. Thesis, Faculté des sciences de Tunis, Tunis.

[27] Agumagu, O. (2016) Observed and Simulated Changes in Precipitation over Sahel Region of West Africa. Journal of Climatology and Weather Forecasting, 163, 1-9.

[28] Favreau, G., Leduc, C., Marlin, C. and Guéro, A. (2002) Une dépression piézométrique naturelle en hausse au Sahel (Sud-Ouest du Niger). [A Risingpiezometric Depression in the Sahel (Southwestern Niger) (Sud-Ouest du Niger).] Comptes Rendus Geoscience, 334, 395-401. https://doi.org/10.1016/S1631-0713(02)01763-7

[29] Dewandel, B., Lachassagne, P., Wyns, R., Maréchal, J.C. and Krishnamurthy, N.S. (2006) A Generalized 3-D Geological and Hydrogeological Conceptual Model of Granite Aquifers Controlled by Single or Multiphase Weathering. Journal of Hydrology, 330, 260-284. https://doi.org/10.1016/j.jhydrol.2006.03.026

[30] Machiwal, D. and Jha, M.K. (2014) Characterizing Rainfall-Groundwater Dynamics in a Hard-Rock Aquifer System Using Time Series, Geographic Information System and Geostatistical Modelling. Hydrological Processes, 28, 2824-2843. https://doi.org/10.1002/hyp.9816

[31] Zougmoré, R., Mando, A. and Stroosnijder, L. (2004) Effect of Soil and Water Conservation and Nutrient Management on the Soil-Plant Water Balance in Semi-Arid Burkina Faso. Agricultural Water Management, 65, 103-120. https://doi.org/10.1016/j.agwat.2003.07.001

[32] Barbier, B., Yacouba, H., Karambiri, H., Zoromé, M. and Somé, B. (2009) Human Vulnerability to Climate Variability in the Sahel: Farmers' Adaptation Strategies in Northern Burkina Faso. Environmental Management, 43, 790-803. https://doi.org/10.1007/s00267-008-9237-9

[33] Zongo, B., Diarra, A., Barbier, B., Zorom, M., Yacouba, H. and Dogot, T. (2015) Farmers' Perception and Willingness to Pay for Climate Information in Burkina Faso. Journal of Agricultural Sciences, 8, 175. https://doi.org/10.5539/jas.v8n1p175

[34] Gates, J.B., Scanlon, B.R., Xingmin, M. and Lu, Z. (2011) Impacts of Soil Conservation on Groundwater Recharge in the Semi-Arid Loess Plateau, China. Hydrogeology Journal, 19, 865-875. https://doi.org/10.1007/s10040-011-0716-3

[35] Yin, L., Hu, G., Huang, J., Wen, D., Dong, J., Wang, X. and Li, H. (2011) Groundwater-Recharge Estimation in the Ordos Plateau, China: Comparison of Methods. Hydrogeology Journal, 19, 1563-1575. https://doi.org/10.1007/s10040-011-0777-3

[36] Sandwidi, W.J.P. (2007) Groundwater Potential to Supply Population Demand within the Kompienga Dam Catchment in Burkina Faso. Ph.D. Thesis, Ecology and Development Series, No. 55, Cuvillier Verlag Göttingen.

[37] Martin, N. and Van de Giesen, N. (2005) Spatial Distribution of Groundwater Production and Development Potential in the Volta River Catchment of Ghana and Burkina Faso. Water International, 30, 239-249. https://doi.org/10.1080/02508060508691852

[38] Sompougdou, T.R. (2008) Evaluation du bilan hydrologique à l'échelle du bassin versant de Tougou (bassin supérieur du Nakambé) Burkina Faso. [Assesment of the Water Balance at Basin Scale, Case of Tougou Watershed (Upper Basin of Nakambé/Burkina Faso) Burkina Faso.] Master Thesis, 2iE, Burkina Faso. 
[39] Niang, D. (2006) Fonctionnement hydrique de différents types de réservoirs de placages sableux dans le sahel Burkinabè. [Hydrological Functioning of Sandy Soil Layers in the Burkina Faso Sahel.] Ph.D. Thesis, Ecole Polytechnique Fédérale de Lausane, Lausane. 